\title{
Intermarriage in the Canonical Tradition of the Orthodox Church ${ }^{1}$
}

\author{
RĂZVAN PERȘA
}

My research tries to re-examine the issue of mixed marriage from the point of view of the Orthodox Canonical Tradition in the broader context of marital and baptismal theology, through an extensive interpretation of the canons of the Orthodox Church regarding intermarriage according to the historical, social, legal, doctrinal, and canonical context of the promulgation of those canons. The interpretation of the canons regarding mixed marriage will try to emphasize the definition of heretical groups in accordance with the baptismal theology and with the manner of reception of heretics into the Orthodox Church that was developed by every Council. In accordance with the Canons of the Council of Laodicea and of the Fourth Ecumenical Council, I will demonstrate that the Church did not stipulate any immediate conversion of the nonOrthodox spouse and the marriage was not grounded on immediate baptism, but on the willingness of the heterodox person to promise and accept Orthodox teachings for a future baptism. In accordance with the interpretation of Canon 72 of the Council of Trullo, I will emphasize that the canonical prohibition of mixed marriage is not a doctrinal one, otherwise the canon would reject any cohabitation between Orthodox and non-Orthodox, but rather it is a pastoral, canonical and disciplinary measurement in order to suppress the spread of heretical doctrines and teachings.

Keywords: intermarriages, mixed marriages, canons, Orthodox Canon Law, Orthodox Tradition, Canon 72 of the Council of Trullo

\section{Preliminary remarks}

As the Catholic scholar Charles Lefebvre argued in his research regarding the origin of the expressions "matrimonia mixta" 2 and "mixta

\footnotetext{
* Răzvan Perșa, Rev. PhD, Assistant Professor at the Faculty of Orthodox Theology, "Babeș Bolyai" University, Cluj-Napoca, Romania. Address: Str. Nicolae Ivan F.N., 400692, Cluj-Napoca, Cluj. Email: persarazvan@gmail.com.

1 This article is a revised version of a presentation made at the international conference Interconfessional Marriages between Orthodox and Protestant Christians, hosted by the Institute for Ecumenical Research within Lucian Blaga University, Sibiu, that took place between $8^{\text {th }}$ and the $9^{\text {th }}$ of March 2018.

2 "Matrimonia mixta" defines marriages between two persons of different Christian denominations or confessions. For the debate regarding mixed marriages between an Orthodox spouse and a non-Orthodox spouse see: Stanley S. Harakas, "Emerging Ecumenical Families", in: Greek Orthodox Theological Review 40 (3-4/1995), p. 347-363; Astrid Kaptijn, "Le statut juridique des enfants mineurs nés des mariages mixtes catholiques - orthodoxes", in: L'année canonique 46 (2004), p. 259-267; Josef Prader, "Die Mischehe zwischen katholischen und orthodoxen
} 
religio"3, this distinction is a product of the modern theory of Canon Law and is influenced by its development. It refers to a marriage between two persons of different confessions ("matrimonia mixta") or religions ("mixta religio"). In the current academic debate, these kinds of marriages are called "mixed marriages", "inter-church marriages", "Intra-Christian Marriages", "Inter-religious Marriages" or "Intermarriages". ${ }^{4}$ On the other hand, the Greek Orthodox Canon-Lawyer Gregorios Papathomas speaks about four types of marriages according to Orthodox Canon Law: canonical marriage, interreligious marriage, inter-Christian marriage, and civil marriage. Unfortunately, we cannot find any of these expressions in the Canonical Tradition of the Orthodox Church. Despite this, as we will see, Canon 31 of the Council of Laodicea uses the noun "kं $\pi \iota \gamma \alpha \mu i \alpha$ ", that can be translated as "intermarriage". It is anachronistic to consider that the Canons of the Church were speaking in that period about the same issue of mixed marriages or inter-Christian marriages as we see it today in a context of Christian denominations, globalisation and pluralistic societies. Nevertheless, a contextual interpretation of the canons can give us a proper understanding of how the Church approached these kinds of marriages from canonical, legal, doctrinal and pastoral perspectives.

The problem of mixed marriages was debated most recently during the pre-conciliar preparation process for the Holy and Great Council of the

Christen mit Bezugnahme auf das Problem der Ehescheidung und Wiederverheiratung”, in: Orientalia Christiana Periodica 49 (1983), p. 164-183; Rudolf Prokschi, "Ist ein kirchlicher Eheabschluss orthodoxer Gläubiger mit Christen anderer Bekenntnisse (Mischehe) möglich?" in: Christoph Ohly, Wilhelm Rees (eds.), Theologia Iuris Canonici Festschrift für Ludger Müller zur Vollendung des 65. Lebensjahres, Kanonistische Studien und Texte 67, Berlin, Duncker \& Humblot 2017, p. 783-797; Lewis J. Patsavos, "A Canonical Response to Intra-Christian and Inter-religious Marriages", in: Greek Orthodox Theological Review 40 (3-4/1995), p. $287-$ 298; Panteleimon Rodopoulos, "Mixed Marriages", in: Kanon. Jahrbuch der Gesellschaft für das Recht der Ostkirchen 6 (1983), p. 87-91; Radko Poptodorov, "Intermarriages in the Orthodox Tradition and Practice of the Slavic Churches", in: Kanon. Jahrbuch der Gesellschaft für das Recht der Ostkirchen 6 (1983), p. 109-114; S. S. Harakas, "An Eastern Orthodox Approach to Marriage in an Ecumenical Context", in: Ecumenism (march/1993), p. 24-27; Alice Scourby, "The Orthodox Church and Intra-Christian Marriages", in: Greek Orthodox Theological Review 40 (3-4/1995), p. 313-319; Anton C. Vrame, Intermarriage: Orthodox Perspectives, Brookline, Holy Cross Orthodox Press 1997; Charles Joanides, Lewis Patsavos, "Interchurch marriages: an Orthodox perspective”, in: Greek Orthodox Theological Review 45 (1-4/2000), p. 433-442.

3 Mihai Iulian Constantinescu, "La différence de religion" comme empêchement au mariage selon la législation et la doctrine canonique de l'Église Orthodoxe et Catholique-Romaine. Un point de vue orthodoxe", in: Constantin Rus, Emilian Roman (eds.), The Christian Family, Iași, Ed. Universității "Alexandru Ioan Cuza” 2013, p. 238-260.

4 Charles Lefebvre, "Quelle est l'origine des expressions «matrimonia mixta" et "mixta religio"”, in: Urbano Navarrete (ed.), Ius populi Dei. Miscellanea in honorem Raymundi Bidagor, vol. III, Roma 1972, p. 359-373. 
Orthodox Church, which, at long last, took place on the Island of Crete in 2016, but not without difficulties. ${ }^{5}$ The scholars tried before and after the Council to bring up an articulated Orthodox point of view regarding intermarriage or mixed marriage. ${ }^{6}$. The final document of the Council, "The Sacrament of Marriage and its Impediments" was voted on by just ten Autocephalous Orthodox Churches and does not express the univocal view of the Orthodox Church until its final reception. Unfortunately, the final formulation of the fifth article "Concerning mixed marriages of Orthodox Christians with non-Orthodox Christians or non-Christians" of the document of the Council of Crete does not articulate a clear attitude of the Orthodox Canonical Tradition, being more confused than the previous formulations where we had the expression of akribeia and oikonomia. ${ }^{7}$ In spite of all this,

5 For an extensive debate regarding the Holy and Great Council of Crete and its decisions see: Eva Maria Synek, Das 'Heilige und Grosse Konzil' von Kreta, Freistadt, Verlag Plöchl Freistadt 2017; Reinhard Thöle, "Ein hohes Ideal zahlt einen hohen Preis. Zur Heiligen und Großen Synode der Orthodoxen Kirche auf Kreta", in: Ökumenische Rundschau 66 (1/2017), p. 6-11; Răzvan Perșa, "The Canonical Tradition of the Orthodox Church and the Holy and Great Council”, in: Studia Universitatis Babes-Bolyai Theologia Orthodoxa 62 (1/2017), p. 39-72.

6 Andrzej Kuźma, "The Documents of the Great and Holy Council of 2016 Concerning the Inner Life of the Orthodox Church", in: Studia Universitatis Babes-Bolyai Theologia Orthodoxa 62 (1/2017), p. 32-34; Iulian Mihai Constantinescu, "De la întrunirile pregătitoare la documentul oficial «Sfânta Taină a Cununiei și impedimentele la aceasta» al Sfântului și Marelui Sinod al Bisericii Ortodoxe. O evaluare juridico-canonică”, in: Patriciu Vlaicu, Răzvan Perșa (eds.), Sfântul și Marele Sinod. Eveniment eshatologic sau normalitate canonică?, Cluj-Napoca, Presa Universitară Clujeană 2018, p. 258-302.

7 The pre-conciliar document regarding marriage stated: "Concerning mixed marriages of Orthodox Christians with non-Orthodox Christians or non-Christians: Marriage between Orthodox and non-Orthodox Christians is forbidden and is not blessed in the Church, according to canonical akribeia (Canon 72 of the Quinisext Ecumenical Council). However, such a marriage can be blessed by dispensation and out of love, on the condition that the children born of this marriage will be baptized and raised within the Orthodox Church. Marriage between Orthodox and non-Christians is categorically forbidden in accordance with canonical akribeia." Despite this clear statement regarding mixed marriages according akribeia and oikonomia the final decision of the Council of Crete stated: "Concerning mixed marriages of Orthodox Christians with non-Orthodox Christians or non-Christians: Marriage between Orthodox and non-Orthodox Christians is forbidden according to canonical akribeia (Canon 72 of the Quinisext Ecumenical Council). With the salvation of man as the goal, the possibility of the exercise of ecclesiastical oikonomia in relation to impediments to marriage must be considered by the Holy Synod of each autocephalous Orthodox Church according to the principles of the holy canons and in a spirit of pastoral discernment. Marriage between Orthodox and non-Christians is categorically forbidden in accordance with canonical akriveia". It is not clear if the passage regarding oikonomia can be applied to all canonical marriage impediments, or just to mixed marriages with non-Orthodox. For the final decisions of the documents, see: Alberto Melloni, Davide Dainese (eds.), Conciliorum oecumenicorum generaliumque decreta: 4, 3: The great councils of the Orthodox churches: decisions and synodika: Crete 2016, Turnhout, Brepols Publishers 2016, p. 1364-1365. 
what can be observed in the texts of all pre-conciliar and conciliar documents is the appeal to the canons of the Church, especially to Canon 72 of the Council in Trullo.

Orthodox scholars often quote the canons in their studies regarding the issue of mixed marriage according to the Canonical Tradition of the Church and the prohibition of marriage with heterodox that can be found in these canons without a contextual interpretation of these texts. ${ }^{8}$ Of course, we can find as well some exceptions and few extensive interpretations of these canons ${ }^{9}$ that present the historical, social, doctrinal, and canonical context of the promulgation of those canons.

\section{Intermarriage according to the canons of the Council of Laodicea}

The first canons from what is called Corpus canonum of the Orthodox Church that approaches the problem of intermarriage or mixed marriage are Canon 10 and 31 of the Council of Laodicea (dated 341-381). ${ }^{10}$ Unfortunately, there are insufficient historical details regarding the date, context, reasons, and sessions of this Council of Laodicea in the province of Phrygia

8 See for example: Lewis J. Patsavos, "Mixed marriages and the canonical tradition of the Orthodox Church", in: Greek Orthodox Theological Review 23 (3-4/1978), p. 244-245; David Heith-Stade, Marriage as the arena of salvation: an ecclesiological study of the marital regulation in the canons of the Council in Trullo, Rollinsford N.H., Orthodox Research Institute 2011, p. 28-35. Ioan Cozma, "Căsătoriile mixte în teoria și practica Bisericii Ortodoxe”, in: Altarul Reintregirii 15 (2/2010), p. 147-166; Even in the Orthodox commentaries on these canons we cannot find an extensive interpretation regarding the text, context, validity and applicability of these canons. See: Peter L'Huillier, The Church of the Ancient Councils: The Disciplinary Work of the First Four Ecumenical Councils, Crestwood, St Vladimir's Seminary Press 1996, p. 242-243; Nicodim Milaș, Canoanele Bisericii Ortodoxe insoțite de comentarii (Canons of the Orthodox Church with commentaries), vol. I.2, trans. Kovincici Uroș, Nicolae Popovici, Arad, Tipografia Diecezană 1931, p. 226-228, 447-450.

9 See for example: Spyridon Troianos, "Die Mischehen in den heiligen Kanones”, in: Kanon. Jahrbuch der gesellschaft für das Recht der Ostkirchen 6 (1983), p. 92-101; Constantinos G. Pitsakis, "Les mariages mixtes dans la tradition juridique de l'Église grecque: de l'intransigeance canonique aux pratiques modernes", in: Etudes balkaniques. Cahiers Pierre Belon 10 (2003), p. 107-145; Patriciu Dorin Vlaicu, "Biserica Ortodoxă în fața problematicii căsătoriilor mixte", in: Studii Teologice 8 (1/2012), p. 167-190. We can mention here as well the article of the Catholic scholar William W. Bassett, "The Impediment of Mixed Religion of the Synod in Trullo (A.D. 691)", in: Jurist 29 (1969), p. 383-415.

10 For the date, context and details regarding this Council, see: Ulrich Huttner, Early

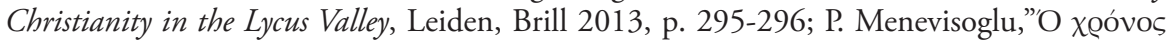

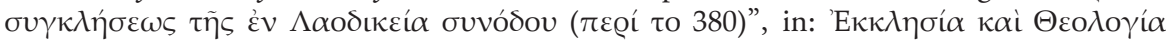
5 (1984), p. 861-874; Heinz Ohme, "Sources of the Greek Canon Law to the Quinisext Council (691/2) Councils and Church Fathers", in: Kenneth Pennington (ed.), The History of Byzantine and Eastern Canon Law to 1500, History of medieval canon law 4, Washington, CUA Press 2012, p. 47-49; Canoanele Bisericii Ortodoxe. Vol. 2: Canoanele Sinoadelor Locale, trans. Răzvan Perșa, Bucharest, Basilica 2018, p. 79-81. 
Pacatiana, and it is very hard to reconstruct these aspects for a contextual interpretation of the canon.

First of all, why does the Council of Laodicea have two canons regarding the same issue of mixed marriage? More scholars tried to explain the existence of two canons for the same topic because two different Councils that promulgated canons took place in Laodicea. This is given by the difference in structure between the first 19 canons of the Council that begin

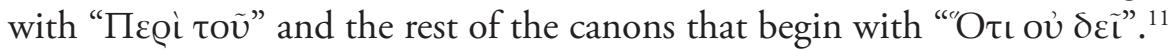
The introduction of the canons of the Council of Laodicea shows that "The holy synod of Laodicea in Phrygia Pacatiana, assembled from [the] several provinces of [the diocese of] Asia, passed ecclesiastical resolutions as listed below". ${ }^{12}$ There is no evidence from external textual criticism to support the idea of two Councils, and there is no manuscript in the Canonical tradition of the Church to give evidence for two Councils. More than that, the Canons of the Council in Laodicea were included in the so-called "Antiochian corpus" 13 as one entity. Even if we admit the existence of two Councils, it is improbable that the last one was unaware of the decisions of the former one or that the bishops who attended the first council did not attend the second one as well. The two canons of the Council of Laodicea state that:

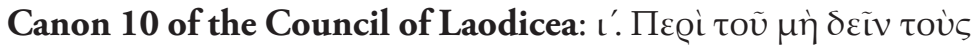

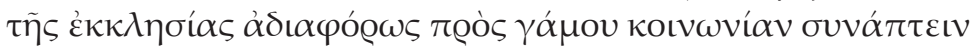

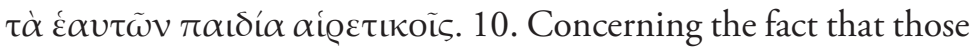

11 The following scholars give arguments for the existence of two Councils of Laodicea: Alexandre Faivre, Naissance d'une hiérarchie: Les premières étapes du cursus clérical, Paris, Beauchesne 1977, p. 228; Périclès Pierre Joannou, Discipline génèrale antique (II $-I X^{e}$ s.), 1.2. Les canons des synodes particuliers (IV $-I X^{e}$ s.), Fonti IX, Série 1, Roma, Grottaferrata 1962, p. 128; H. Ohme, Kanon Ekklesiastikos: Die Bedeutung des Altkirchlichen Kanonbegriffs, Arbeiten Zur Kirchengeschichte 67, Berlin - New York, Walter de Gruyter 1998, p. 403; S. Troianos, "Die Mischehen”, p. 95.

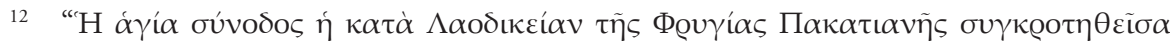

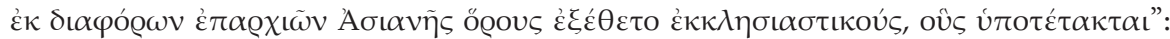
Engbert Jan Jonkers, Acta et symbola conciliorum quae saeculo quarto habita sunt, Leiden, Brill 1954, p. 86.

13 For the existence of an "Antiochian Corpus" of canonical decisions see: Eduard Schwartz, "Die Kanonessammlungen der alten Reichskirche," in: Zeitschrift der Savigny-Stiftung für Rechtsgeschichte, Kan. Abt. 25 (1936), p. 1-114; P. L'Huillier, "Origines et développement de l'ancienne collection canonique grecque," in: Messager de l'Exarchat du Patriarche russe en Europe occidentale 24 (1976), p. 53-65; Aram Mardirossian, La collection canonique d'Antioche: droit et hérésie à travers le premier recueil de législation ecclésiastique, IVe siècle, Paris, Centre de Recherche d'Histoire et Civilisation de Byzance 2010, p. 42; David Wagschal, Law and Legality in the Greek East: The Byzantine Canonical Tradition, 381-883, Oxford, Oxford University Press 2015, p. 32-34. 
of the Church shall not unite their children with indifference in the communion of marriage with heretics. ${ }^{14}$

Canon 31 of the Council of Laodicea: $\lambda \alpha{ }^{\prime} . ~ ' O \tau \iota$ oủ $\delta \varepsilon \tilde{\imath} \pi \varrho o ̀ s$

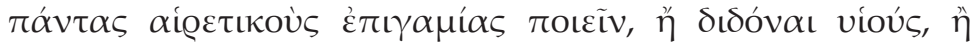

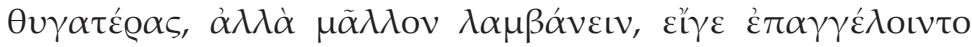

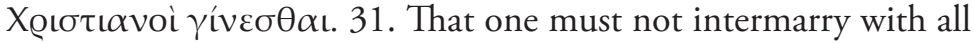
heretics, or give one's sons or daughters to them, but rather one ought to take theirs, if they should promise to become Christians.

First of all, we can observe that these canons have no variants or alterations in the Greek manuscript tradition ${ }^{15}$ and by this the problem of textual criticism is excluded.

The interpretation of Canon 10 of Laodicea has to take into consider-

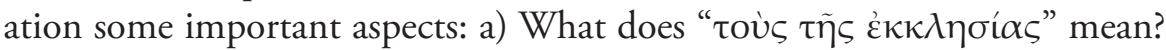

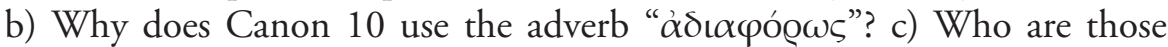

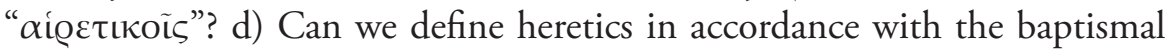
theology and with the manner of reception of heretics into the Orthodox Church from the parallel canons of the Council of Laodicea?

14 This is my own translation according to the Greek text. For other English translations of the canons of Laodicea see: Henry R. Percival, "The Seven Ecumenical Councils of the Undivided Church: Their Canons and Dogmatic Decrees, together with the Canons of all the Local Synods which have Received Ecumenical Acceptance", in: Philip Schaff (ed.), Nicene and Post-Nicene Fathers, vol. 14, Oxford-New York, Benediction Classics 1900, p. 129; G.B. Howard, The Canons of the Primitive Church Together with the Creeds of Nicaea and Constantinople and the Definition of the Faith Set Forth at Chalcedon, London, James Parker 1896, p. 165-174; Nicodemus the Hagiorite, Agapius the Monk, The Rudder (Pedalion) of the Metaphorical Ship of the One Holy Catholic and Apostolic Church of Orthodox Christians, trans. D. Cummings, Chicago, The Orthodox Christian Educational Society 1957, p. 551578; John Fulton, Index canonum: the Greek text, an English Translation, and a Complete Digest of the Entire Code of Canon Law, London, Wells Gardner 1883, p. 250-269. For the Greek text, see: P. P. Joannou, Discipline génèrale antique, p. 130-155; Hamilkar. S. Alivi-

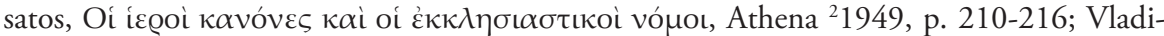
mir N. Beneševič, Syntagma XIV titulorum sine scholiis secundum versionem paleo-slovenicam adjecto textu graeco e vetutissimis codicibus manuscriptis exarato, St. Petersburg, Otdielenie russkago iazyka i slovesnosti Imp. Akademii nauk, 1906, p. 267-279; Friedrich Lauchert (ed.), Die Kanones der wichtigsten altkirchlichen Concilien: Nebst den apostolichen Kanones, Sammlung ausgewählter kirchen- und dogmengeschichtlicher Quellenschriften 12, Freiburg im Breisgau, Akademische Verlagsbuchhandlung von J. C. B. Mohr 1896, p. 72-79; J. Ful-

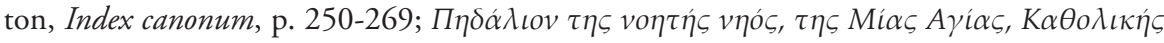

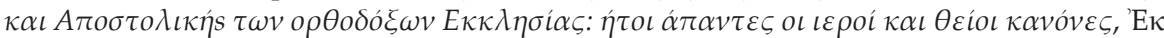

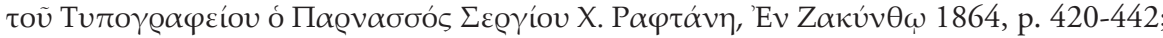
Jean-Baptiste Pitra, Juris ecclesiastici Graecorum historia et monumenta, vol. 1, Roma, Typis S. Congregationis De Propaganda Fide 1864, p. 495-504; Georgios A. Rhalles, Michael Potles

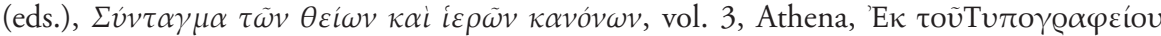

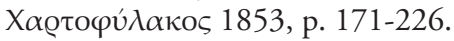

15 V. N. Beneševič, Syntagma XIV titulorum, p. 269, 273. 


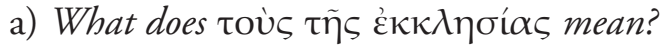

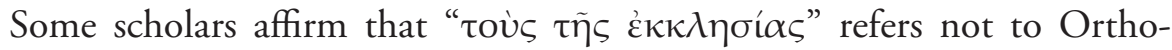
dox believers in general, but to clergy ${ }^{16}$, the canon being applied just to the upper and lower clergy. This interpretation is based on the fact that

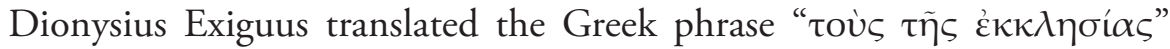
into Latin with ecclesiasticos" 17 . The argument for supporting this kind of interpretation is insufficient for the following reasons. The so-called Isidoriana - another Latin translation of the canons - renders the expres-

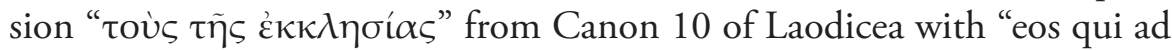
ecclesiam pertinent" ("those who belong to the Church") ${ }^{18}$. Canon 9 of

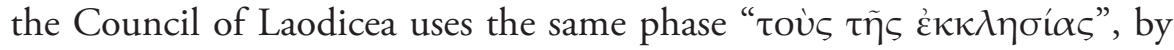
affirming that:

Concerning the fact that those belonging to the Church ( $\dot{\varepsilon} \kappa \kappa \lambda \eta \sigma i ́ \alpha \varsigma)$ must not be allowed to go visiting the cemeteries of the so-called martyria of any heretics, for the purpose of prayer or of cure, but, on the contrary, those who do so, if they be among the faithful, shall be excluded from communion for a time until they repent and confess their having made a mistake, when they may be readmitted to communion. ${ }^{19}$

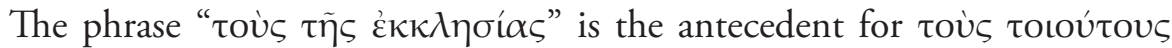
("those who do so") and agrees in person, number and gender. The con-

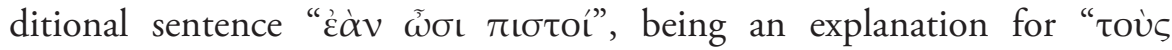

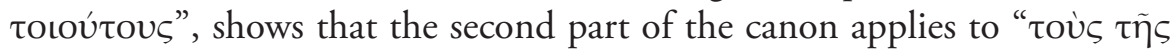

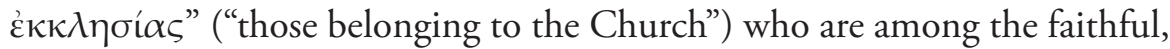
or who are laymen, and not to all the members of the Church. The Latin translation of Dionysius Exiguus follows the same syntactical structure of

16 Constantinos G. Pitsakis, "Les mariages mixtes", p. 107-109. Grigorios D. Papathomas translated this phrase by: "les membres du clergé". This paraphrase can be seen just as an interpretation of the phrase and not as an accurate translation of the Greek text. G. D. Papathomas, Le Corpus Canonum de l'Église (1 $1^{e r}-9^{e}$ siècle). Le texte des Saints Canons ecclésiaux, Katherini, Ed. Epectasis 2015, p. 515.

17 "De his qui cum hereticis nuptiarum copula iunguntur: Quod non oporteat indifferenter ecclesiasticos ad foedera nuptiarum hereticis suos filios filiasque coniungere": Adolf Strewe, Die Canonessammlung des Dionysius Exiguus in der ersten Redaktion, Berlin, De Gruyter, p. 53; P. P. Joannou, Discipline générale antique, p. 134. J. B. Pitra, Juris ecclesiastici Graecorum, vol. 1, p. 496.

18 Cuthbert Hamilton Turner (ed.), Ecclesiae Occidentalis monumenta iuris antiquissima canonum et conciliorum graecorum interpretationes latinae, vol. II, Oxford, Clarendoniano 1907, p. 350.

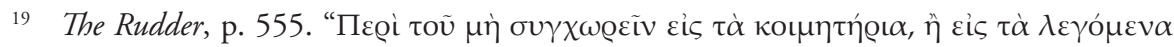

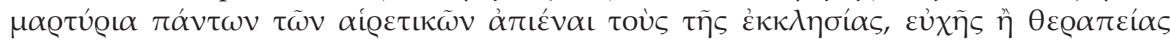

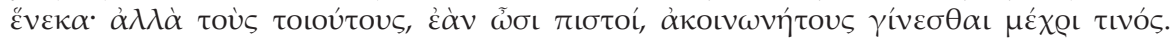

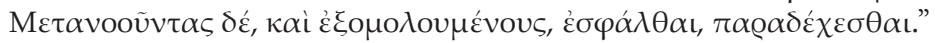




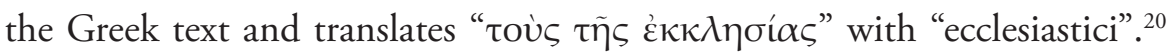
The word "huiusmodi" refers to these "ecclesiastici", agreeing with it in person, number and gender. Dionysius uses the noun "fideles" to translate the Greek word " $\pi \iota \sigma \tau o$ "'. ${ }^{21}$ In the translation of Isidoriana we can find the word

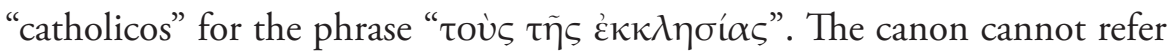
just to laymen, ${ }^{22}$ otherwise it would not have the conditional sentence: " $\dot{\varepsilon} \dot{\alpha} v$

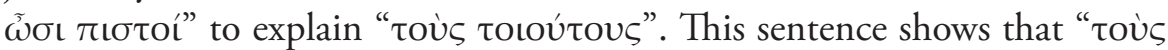
$\tau \tilde{\eta} \varsigma \dot{\varepsilon} \kappa \kappa \lambda \eta \sigma i \alpha \varsigma$ " is a larger category than " $\pi \iota \sigma \tau o$ ", and that the last one is included in the first one. Taking all these into consideration, we can affirm

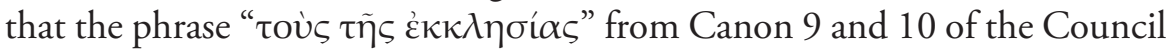
of Laodicea refers both to clergymen and to laymen. ${ }^{23}$

20 "Quod non permittantur ecclesiastici ad haereticorum coemiteria, uel ab ea, quae ab eis appellantur martyria, orationis causa, uel sanitatis accedere: sed huiusmodi, si fideles fuerint, certo tempore communione priuari: poenitentes autem, et confitentes se deliquisse, conuenit suscipi”. C.H. Turner, Ecclesiae Occidentalis, p. 349.

21 A. Strewe, Die Canonessammlung, p. 53.

22 See, for example, the interpretation of Laszlo Odrobina, Le Cth. 3,7,2 el les mariages mixtes, Acta Antiqua et Archaeologica 31, Szeged, Acta Universitatis Szegediensis 2007, p. 134-135.

23 In the explanatory footnote from the Rudder (Pidalion) of Nicodemus the Hagiorite we can find this interpretation: "For precisely as this Council in the above canon IX forbade members of the Church from going to the cemeteries of heretics, including both clerics and faithful laymen as it itself explains this, so and in like manner also in the present Canon in saying that members of the Church must not marry heretics it means both clerics and Christian laymen." The Rudder, p. 556. The byzantine Canonists have different opinions regarding the meaning of the phrase. Zonaras affirms in his commentary on Canon 9 of Laodicea that the canon says: "those of the Church, not the priests or the clergymen, but the believers, that

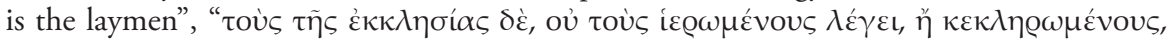

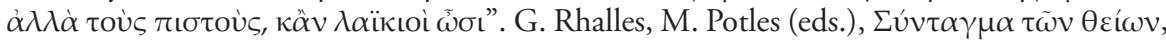
vol. 3, p. 179-180. In the commentary on Canon 14 of the $4^{\text {th }}$ Ecumenical Council, Zonaras says that: "But the Council of Carthage, as the present canon, speaks just about clergymen, but that of Laodicea and the Council of Trullo totally forbid any orthodox believer to unite through marriage with heretics and command that such a marriage, if it is completed, to be dissolved". Balsamon refers just to the believers and makes no mention of clergymen. G. Rhalles, M. Potles (eds.), $\Sigma u ́ v \tau \alpha \gamma \mu \alpha \tau \tilde{\omega} v \theta \varepsilon i ́ \omega v$, vol. 3, p. 180. For a different English translation see: Patrick Viscuso, "Marriage between Orthodox and Non-Orthodox: A Canonical Study", in: Greek Orthodox Theological Review 40 (1-2/1995), p. 230. Nicodim Milaș agrees

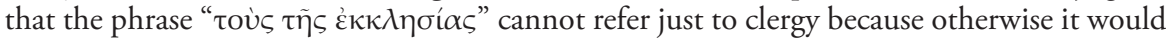
be impossible to understand who are the " $\pi ı \sigma \tau o$ '" from Canon 9 of Laodicea. N. Milaș, $\mathrm{Ca}$ noanele Bisericii Ortodoxe, vol. II.1, trans. K. Uroș, N. Popovici, Arad, Tipografia Diecezană

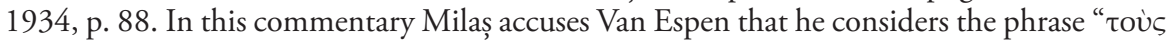

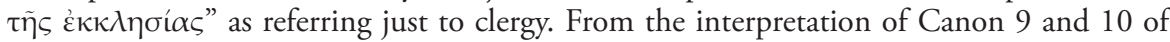
Laodicea found in the work of Van Espen we can see that this accusation is precarious because Van Espen says: "Ex textu Greco, uti ex versione Isidori, sat manifester est hic agi generaliter de omnibus Fidelibus, ideoque vocem Ecclesiastici qua utitur Dionysius, accipiendam in latiore significatione pro omnibus qui sunt Ecclesiae: cui consonant Ferrandus Canonem ita reddens, ut non licet in Haereticorum caemeteria ad orationem faciendam Catholicis accedere." 
b) Why does the canon use the adverb " $\delta \delta \alpha \varphi$ ó $\rho \omega \varsigma$ " (adiaphorous, indifferently, indiscriminately)?

Does it mean that the canon allows marriages with certain heretics if they are not careless or unconcerned, ${ }^{24}$ or that the issue of these kinds of marriages has to be approached with attention and not to be considered a matter of indifference?25 If we analyse the translations of " $\alpha \delta \iota \alpha \varphi$ ó $\omega \varsigma$ " into other ancient and modern languages we can observe that this is in relation to the manner in which the canon and the issue of mixed marriage is understood by the translator. The Latin translation of the Greek adverb " $\alpha \delta \iota \alpha \varphi$ ó $\omega \varsigma$ " is "indifferenter" ${ }^{26}$ For the English translation we can find: "indifferently and without distinction", 27 "not carelessly and unconcernedly", ${ }^{28}$ or "indiscriminately". ${ }^{29}$ The last one is in favour of the possibility of mixed marriages between orthodox and some heretics. ${ }^{30}$

The interpretation of this adverb is dependent on the source of the canons. If we accept the idea that the canons were promulgated by two Councils, ${ }^{31}$ then there is no connection between Canon 10 and Canon 31 of Laodicea, and they can be explained separately. ${ }^{32}$ But if we accept the fact that the canons were given just by one council, that could lead

Zergen Bernard van Espen, Franz Wilhelm Metternich, Commentarius in canones iuris veteris ac noui et in Ius nouissimum: opus posthumum hactenus ineditum, Coloniae Agrippinae 1777,

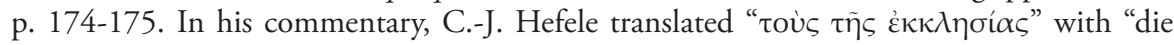
Glieder der Kirche (the members of the Church)", see: Carl Joseph von Hefele, Conciliengeschichte, vol. 1, Freiburg im Breisgau, Herder'sche Verlagshandlung 1873, p. 756.

24 Johannes Haiduk, Mischehe: Eine pastoral-historische Untersuchung der Mischehe von der apostolischen Zeit bis zum Konzil von Agde (506), Düren 1965, p. 90; Bernhard Häring, "Mariage Mixte et Concile", in: Nouvelle Revue Théologique 84 (7/1962), p. 701. Morolli D. Ceccarelli, "I matrimoni misti alla luce dei Sacri Canones del primo millennio", in: Nicolaus 12 (2/1995), p. 138-139.

25 C. G. Pitsakis, "Les mariages mixtes”, p. 107-109.

26 Both Latin translations use "indifferenter" for " $\alpha \delta \iota \alpha \varphi$ ó $\omega \varsigma$ ”. In some manuscripts of Dionysii I we can find "indifferentur" instead of "indifferenter". See: A. Strewe, Die Canonessammlung, p. 53.

27 G. B. Howard, The Canons, p. 48; The French translation of the Greek adverb: " $\alpha \delta \iota \alpha \varphi o ́ \varrho \omega \varsigma$ ", following the same Latin translation, is: "indifféremment". See: P. P. Joannou, Discipline générale antique, p. 134. Unfortunately, the French translation of Archim. Grigorios D. Papathomas leaves out the word: " $\alpha \delta \iota \alpha \varphi$ ó $\omega \varsigma$ ": "Il ne faut pas que les membre du clergé accordent en mariage leurs fils et leurs fille à des hérétiques". G. D. Papathomas, Le Corpus Canonum, p. 515.

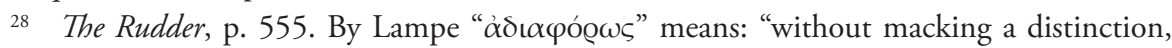
indifferently".

29 Henry R. Percival, “The Seven Ecumenical Councils”, p. 128; John Fulton, Index canonum, p. 253.

30 J. Haiduk, Mischehe, p. 90; B. Häring, "Mariage Mixte", p. 701.

31 S. Troianos, "Die Mischehen”, p. 94-95, L. Odrobina, Le Cth. 3,7,2, p. 135-137.

32 L. Odrobina, Le Cth. 3,7,2, p. 136. 
us to the idea that Canon 31 of Laodicea is an explanation for the meaning of the word " $\alpha \delta$ t $\alpha \varphi$ ó $\omega \varsigma$ ". ${ }^{33}$ It is doubtful to consider that Canon 10 makes a distinction between those heretics with whom Orthodox believers and even clergy can marry, allowing mixed marriages that are not made " $\alpha \delta \iota \alpha \varphi o ́ \varrho \omega \varsigma$ ", but Canon 31 forbids marriages with 'all heretics", if they do not convert to Christianity. According to these arguments it is possible to affirm that " $\alpha \delta \iota \alpha \varphi o ́ \varrho \omega \varsigma$ " does not mark a difference between heretics with whom members of the Church can marry or not, but it highlights the fact that Orthodox parents should not treat this problem with indifference. ${ }^{34}$

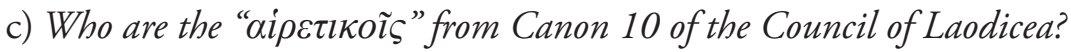

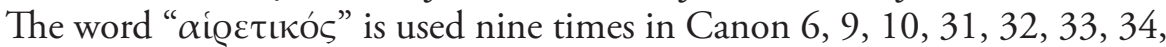
37 of the Council of Laodicea. The details that the canons of the Council are giving us about the heretics of those times are really important for the interpretation of the issue of mixed marriage according to the Council of Laodicea. From Canon 9 we can see that heretics had such financial support that they were able to lay out their own cemeteries and construct funeral chapels for their martyrs. ${ }^{35}$ According to these canons, heretics were not allowed to come into the house of God if they persisted in heresy (Canon 6); the members of the Church were not allowed as well to visit the cemeteries and the so-called shrines of martyrs of heretics (Canon 9); to marry or to give their children to marriage with heretics (Canon 10,31); to accept the blessings of heretics (Canon 32), to join in prayer with heretics or schismatics (Canon 33); to go away to the false martyrs of the heretics (Canon 34), or to accept holiday tokens from heretics (Canon 37). As we can observe, any communion or dialog between Orthodox believers and heretics was forbidden. If this kind of dialog was prohibited how would it be possible for an Orthodox believer to marry a non-Orthodox or heretic person?

Despite this, Canons 7 and 8 of the Council of Laodicea make mention of four heretical groups by name, in Canon 7 the Novatianists, Photinians, and Quartodecimans ${ }^{36}$ and in Canon 8 the Montanists returning

33 J. Haiduk, Mischehe, p. 90.

34 This interpretation can be found as well by: N. Milaș, Canoanele Bisericii Ortodoxe, vol. II.1, p. 88; Georg Daniel Fuchs, Gottlieb Planck, Bibliothek der Kirchenversammlungen des vierten und fünften Jahrhunderts, II, Leipzig, C. G. Hertel 1784, p. 324 accepted by C.-J. Hefele, Conciliengeschichte, vol. 1, p. 756.

35 U. Huttner, Early Christianity, p. 299.

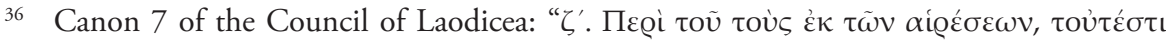

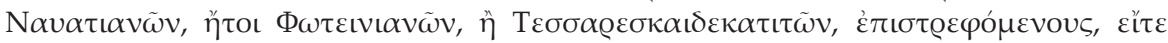

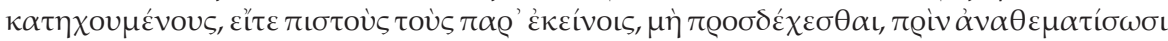

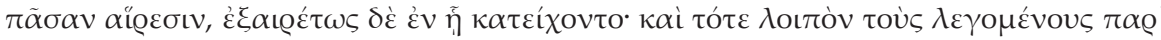

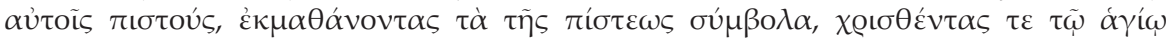

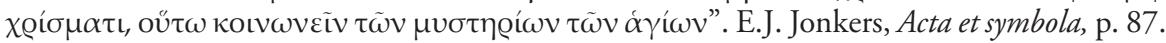




\section{Răzvan Perșa}

from the heresy of the so-called Phrygians. ${ }^{37}$ The rejection of the Quartodecimans ${ }^{38}$ was made in order to reduce any Jewish influences in the Christian communities and to apply the decision of the Council of Nicaea regarding the celebration of Easter. It is thought that the Novatianists were guided as well in the calculation of their Easter date by the Jewish 14 Nissan. ${ }^{39}$ It is probable that the Council of Laodicea rejected them because of their Jewish influences. Regarding Photianians, it is known that Photinus de Sirmium ${ }^{40}$ was a supporter of Marcellus of Ancyra ${ }^{41}$ and was bishop of Sirmium from 343-344, being deposed in 351, due to his anti-Trinitarian heresies. Some Latin collections of canons do not contain the name of the Photinians in canon 7 of the Council of Laodicea, this argument being used against a precise date of the Council of Laodicea ${ }^{42}$. The baptism of Montanists is totally rejected due to their radical anti-trinitarian teachings. According to a twelfth-century inscription, it is believed that the Council of Laodicea took place in order to reject the doctrine of the Montanists. ${ }^{43}$

What is really important to mention here is the difference in the acceptance of those returning from these heresies, despite the fact that all four groups are heretics or profess heretical doctrines. The heretical groups mentioned in Canon 7 did not have to be submitted to baptism, or to be re-baptised, but after a certain period of instruction in the Orthodox faith, all that was necessary was chrismation. ${ }^{44}$ The initiation of the Montanists was more radical involving the fact that they had to be catechized and baptized by the Church, according to Canon 8. As we can see, a special distinction between

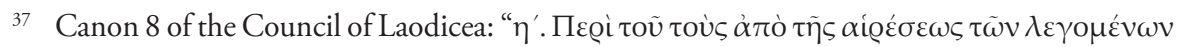

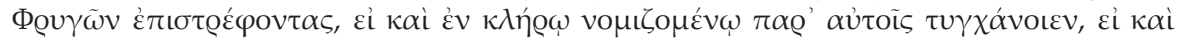

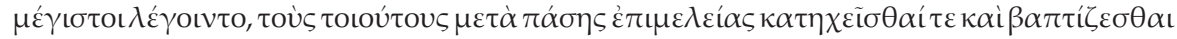

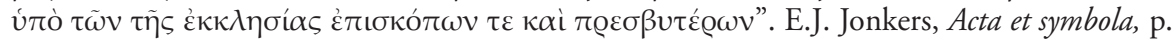
87. For a description of these heretical groups see: U. Huttner, Early Christianity, p. 300.

38 For the doctrine of Quartodecimans in this period, see: Jan Krans, Joseph Verheyden (eds.), Patristic and Text-Critical Studies: The Collected Essays of William L. Petersen, Leiden, Brill 2011, p. 204-2015.

39 For a debate regarding this topic see: U. Huttner, Early Christianity, p. 300.

40 Daniel H. Williams, "Monarchianism and Photinus of Sirmium as the persistent heretical face of the fourth century", in: Harvard Theological Review 99 (2/2006), p. 187-206; Leslie W. Barnard, "Marcellus of Ancyra and the Eusebians", in: Greek Orthodox Theological Review 25 (1/1980), p. 63-76.

41 Friedrich Loofs, "Die Trinitätslehre Marcell's von Ancyra und ihr Verhältnis zur älteren Tradition”, in: Friedrich Loofs et al. (eds.), Patristica: Ausgewählte Aufsätze zur Alten Kirche, Berlin, De Gruyter 1999, p. 123-142.

42 U. Huttner, Early Christianity, p. 295-296.

43 For the inscription see: William Tabbernee, Fake Prophecy and Polluted Sacraments: Ecclesiastical and Imperial Reactions to Montanism, Leiden - Boston, Brill 2007, p. 302.

44 U. Huttner, Early Christianity, p. 300. 
these heretical groups is made, those returning through chrismation and those returning from heresy through baptism, whose baptism was considered to be invalid, despite the fact that all come from heresy, Novatianists, Photinians,

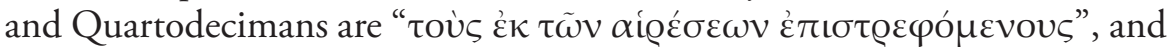

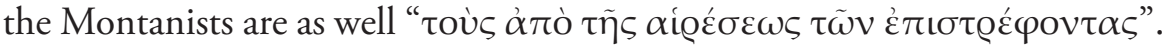
Do these canons imply a special distinction between the canonical meaning of heresy and the doctrinal one and that all heretical groups come from heresies and profess heretical teaching, but not all are received in the Church according to the same canonical procedure?

In connection with Canon 7 and 8 of the Council, the important question that has to be asked for our topic is: why does Canon 10 of the Council of Laodicea forbid all members of the Church to marry heretics, this interdiction being applied after that to "all heretics" according to the first part of Canon 31 of Laodicea?

Despite the fact that some scholars consider that Canon 31 just reiterates Canon 10 of Laodicea, ${ }^{45}$ by comparing the two canons, we can observe the following details. Canon 10 of Laodicea forbids Orthodox parents to indifferently unite their children with heretics in the communion of marriage, but Canon 31 allows for this possibility under some particular conditions ( $\dot{\alpha} \lambda \lambda \dot{\alpha} \mu \tilde{\alpha} \lambda \lambda$ ov). The two canons of the Council of Laodicea do not stipulate any canonical punishment for those who do not respect the decisions of the Council, representing the general vision of the Father assembled in this Council. Canon 31 of Laodicea refers to three different kinds of mixed mar-

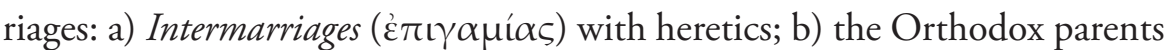

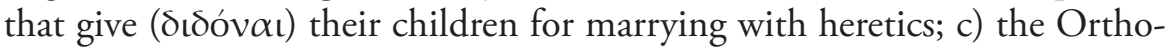
dox parents that receive $(\lambda \alpha \mu \beta \alpha \dot{\alpha} v \varepsilon t v)$ children of heretics to marry with their own children. As we can see, Canon 31 includes not just the parents but the children as well, prohibiting them from intermarrying with heretics. The second canon is more accurate than the first one, including all these kinds of marriage. ${ }^{46}$ As we can see, Canon 31 differentiates between giving children for marriage to heretics and receiving the children of heretics into marriage with Orthodox believers. In the last case, the canon permits the mixed marriage if the heretic spouse "promises to become Christians".

Does this promise involve an immediate conversion of the heretic to Christianity? In order to answer this question we have to see what if they

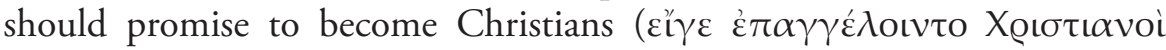

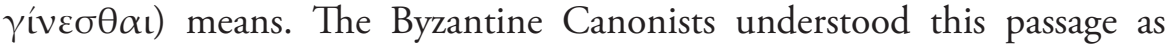
an obligation of the heterodox part to convert to Christianity before the

45 Catherine Caridi, "Marriage between Orthodox and Roman Catholics", in: St Vladimir's Theological Quarterly 53 (4/2009), p. 411.

46 L. Odrobina, Le Cth. 3,7,2, p. 137. 


\section{Răzvan Perșa}

marriage ${ }^{47}$ but this interpretation is really doubtful. First of all, the Canon

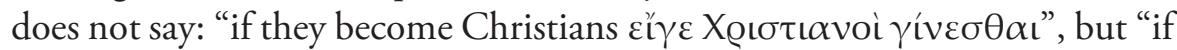

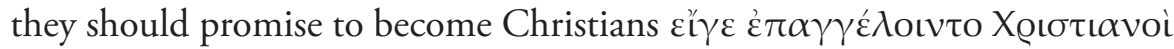

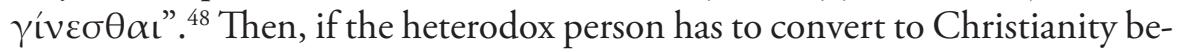
fore the wedding, we would not have any problem and the canon would be superfluous because this kind of marriage would be between two Orthodox believers and not between a heterodox person and an Orthodox believer. ${ }^{49}$

Some scholars affirm that this canon refers just to the heretics who were not considered Christians by the Church, and who have to be re-baptised. $\mathrm{S}$. Troianos considers that the distinction cannot be made before the Second Ecumenical Council..$^{50}$ Despite that, we saw that the canons of Laodicea made such a distinction in Canon 7 and 8 between heretics who have to be re-baptised and heretics who have to be received in the Orthodox Church just with chrismation. Canon 33 of the Council of Laodicea speaks about heretics and schismatics as well: "O

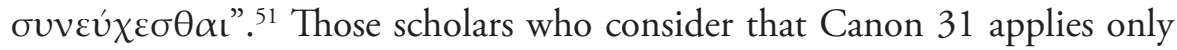
to non-Trinitarian heretics understand the phrase "Xอı in accordance with the modern usage of the term "Christian" and "Christian denomination" as a distinct religious body within Christianity. According

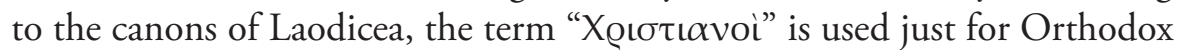
believers and does not include other distinct Christian bodies as the modern

\footnotetext{
47 "But also if the heretic or unbeliever promises to accept the Orthodox faith, then the agreement goes further, but the union is postponed until the one who has done it has fulfilled its promise. And whoever violates these can be subjected to canonical punishment". G. A. Rhalles, M. Potles (eds.), $\Sigma u ́ v \tau \alpha \gamma \mu \alpha \tau \tilde{\omega} v \theta \varepsilon i ́ \omega v$, vol. 2, p. 252-254. As well, Nikodemus the Haghiorite says in the commentary on Canon 14 of the Fourth Ecumenical Council: "But if the heretic should promise to become an Orthodox Christian, let him first become one in accordance with his promise, and then let the marriage be performed." The Rudder, p. 260. For the theology of marriage in the Rudder see: Patrick Vicuso, "The Theology of Marriage in the Rudder of Nikodemos the Hagiorite", in: Östkirchliche Studien 41 (1992), p. 187-207.

48 Patriciu Dorin Vlaicu, "Biserica Ortodoxă în fața problematicii căsătoriilor mixte”, in: Studii Teologice 8 (1/2012), p. 175.

49 S. Troianos, "Die Mischehen”, p. 95.

50 "Diese Interpretation muß aber abgelehnt werden, da die Differenzierung des Verfahrens beim Übertritt zum rechten Glauben erstmalig im Kanon 7 des II. Okum. Konzils auftaucht und jede Rechtfertigung fehlt, daß man sie vorverlegt. Zusätzlich muß erwähnt werden, daß jede Unterscheidung der Häretiker im Hinblick auf die juristische Möglichkeit, eine Mischehe einzugehen, von den beiden Interpretoren Zonaras und Balsamon in ihren Scholien zum Kanon 31 von Laodicea abgelehnt wird”, S. Troianos, "Die Mischehen”, p. 95.

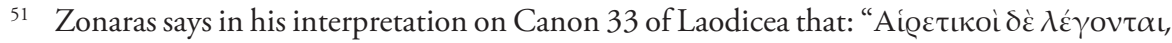

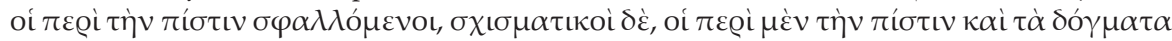

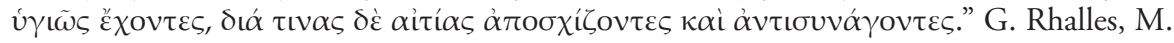
Potles (eds.), $\Sigma \dot{v} v \tau \alpha \gamma \mu \alpha \tau \tilde{\omega} v \theta \varepsilon i ́ \omega v$, vol. 3, p. 199.
} 
term does. ${ }^{52}$ The other religious communities are called: "heretics", "schismatics" (Canon 33), "Jews" (Canon 29), ${ }^{33}$ "pagans" (Canon 30). What is really important in both canons of the Council of Laodicea is the fact that schismatics are not mentioned at all, despite the fact that Canon 33 forbids Orthodox from praying with heretics and schismatics. According to this distinction both canons do not include schismatics in their interdiction. ${ }^{54}$ But even if we have the possibility of a marriage between an Orthodox person and a heretic who becomes Christian, there is a real problem regarding any service or blessing from the Church. As we have mentioned, it was forbidden for a heretic to come into the house of God, if they persist in heresy (Canon 6); the members of the Church were not allowed to accept the blessings of heretics (Canon 32), or to join in prayer with heretics and schismatics as well (Canon 33). Any possibility of a Church service in the heretical community was forbidden for the Orthodox party, and any divine service in the Orthodox Church was forbidden for the heretical person, who was not allowed even to enter the Church. ${ }^{55}$ So, does the Orthodox Church accept the heretical person if he should promise to convert and accept this marriage, but without an official blessing in the Church? From the historical point of view, we can see that the blessing of a priest was obligatory and normative for the validity of marriage only the beginning of the $10^{\text {th }}$ century when Emperor Leon VI issued a law (Novella 89 ) around $907^{56}$ regarding this problem. ${ }^{57}$ From this period onward a legitimate marriage involved an official religious solemnization..$^{58}$

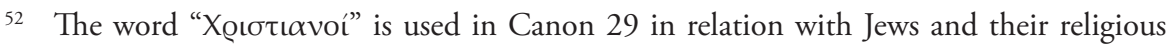

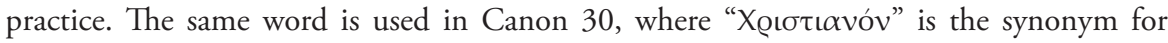

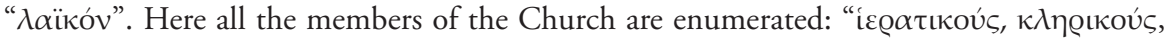

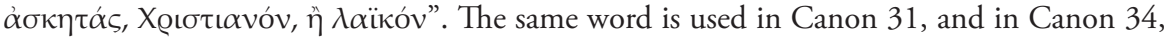
where it is obvious that the canon refers to Orthodox believers in contradiction with heretics,

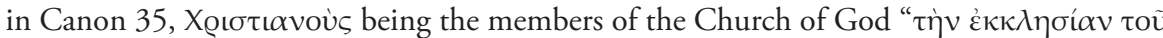
$\Theta \varepsilon o \tilde{v}$ ", in Canon 53, where the word is used as designating in general the members of the Church.

53 See for more details: U. Huttner, Early Christianity, p. 298-299.

54 S. Troianos, "Die Mischehen”, p. 90; L. J. Patsavos, "Mixed marriages”, p. 245.

55 L. Odrobina, Le Cth. 3,7,2, p. 137-138.

56 P. L'Huillier, "Novella 89 of Leo the Wise on marriage: an insight into its theoretical and practical impact", in: Greek Orthodox Theological Review 32 (2/1987), p. 157.

57 P. L'Huillier, "Novella 89", p. 153-162; Clarence Gallagher, "Marriage in Eastern and Western Canon Law Main Article”, in: Law \& Justice-The Christian Law Review 157 (2006), p. 9.

58 This normativity is given today as well for the Orthodox Church of Greece. See: Constantin Vavouskos, "Les mariages mixtes d'après le droit en vigueur en Grèce", in: Kanon. Jahrbuch der gesellschaft für das Recht der Ostkirchen 6 (1983), p. 102-108. 
Răzvan Perșa

\section{Intermarriage according to the canons of the councils of the fifth century}

The next Canon from the Collection of Canons of the Orthodox Church that speaks about mixed marriages is Canon 21 of the Council of Carthage:

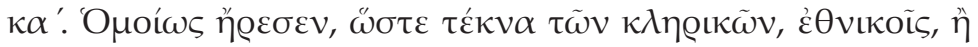

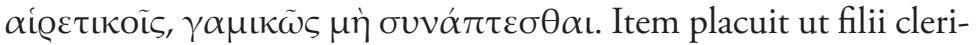
corum gentilibus vel hereticis matrimonio non coniugantur.

The Council of Carthage, following the canonical practice of convening the Biannual General Synod of Africa, gathered between May $25^{\text {th }}$ and $30^{\text {th }}, 419$, in order to discuss some issues regarding jurisdiction between the Church of Rome and the Churches of Africa. The first session of the Council was on the $25^{\text {th }}$ May 419, and opened by reading the acts of the Council of Nicaea, and by discussing the decisions taken by previous African Councils. This first session of the Council accepted 28 canonical decisions of previous councils from Africa that represent the first 28 canons of the Council of Carthage. ${ }^{59}$ Canons 14-24 were taken from the decisions of the Council of Hippo, that took place on $15^{\text {th }}$ October 393. This Council of Hippo in its Canon 12 states that: "Placuit ut filli vel filiae episcoporum, vel quorumlibet clericorum gentilibus vel haereticis vel schismaticis matrimonio non iugantur". As we can see, the Council forbids any marriage between children of clergy and pagans, heretics and schismatics as well. Despite this, Canon 21 of the Council of Carthage leaves out the word "schismatics" and only forbids marriage with pagans and heretics. Does it mean that a difference between "heretics" and "schismatics" was made at this Council and that marriage with "heretics" were totally forbidden for the children of clergymen but the marriage with "schismatics" were tolerated but not encouraged? ${ }^{60}$ The answer for this question can be found in the canonical legislation of the fifth century.

One of the most important canons regarding mixed marriage in the fifth century is Canon 14 of the Fourth Ecumenical Council. Taking into consideration that the Churches of the East and West accepted this Council as the fourth Ecumenical one, its canonical provisions were considered normative for the entire Church.

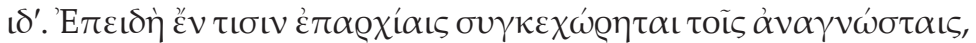

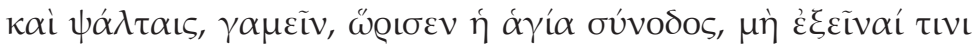

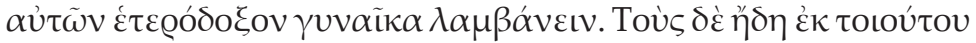

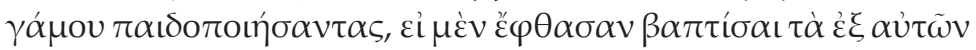

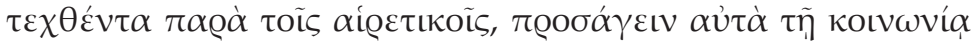

59 For a complete list of the African Councils and canons see: P. P. Joannou, Discipline générale antique, p. 194-196.

60 L. J. Patsavos, “Mixed marriages”, p. 245-246; C. Caridi, “Marriage between”, p. 414. 


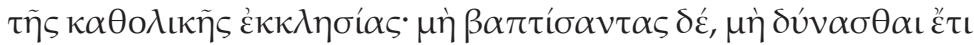

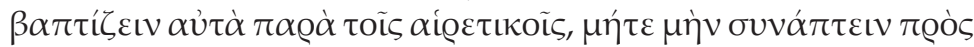

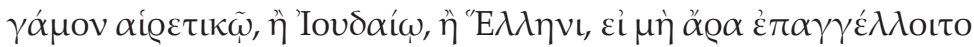

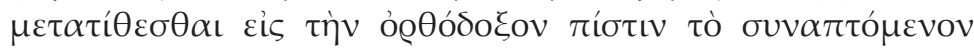

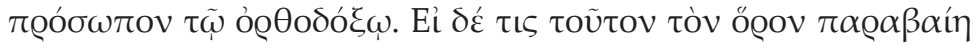

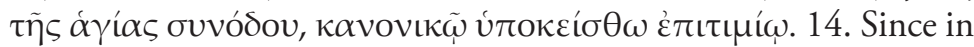
certain provinces readers and cantors have been allowed to marry, the sacred synod decrees that none of them is permitted to marry a heterodox wife. If those have already had children from such a marriage, and if they have already had the children baptised by heretics, they are to bring them into the communion of the catholic church. If they have not been baptised, they may no longer have them baptised among heretics; nor indeed marry them to a heretic or a Jew or a Greek, unless of course the person who is to be married to the Orthodox party promises to convert to the Orthodox faith. If anyone transgresses this decree of the sacred synod, let him be subject to a canonical penalty. ${ }^{61}$

As we can observe from its text, Canon 14 of the Council of Chalcedon reaffirms all the previous canonical decisions regarding mixed marriage. It is improbable that the Fathers of the Church were influenced by the canon of Carthage, but what it is more likely is that they knew the decisions of the Council of Laodicea, taking into consideration that its decisions were part of the codex of canons used by the Fathers at the Fourth Ecumenical Council. ${ }^{62}$ Canon 14 of the Fourth Ecumenical Council can be considered as an extensive explanation of Canon 31 of the Council of Laodicea. This canon raises the same canonical

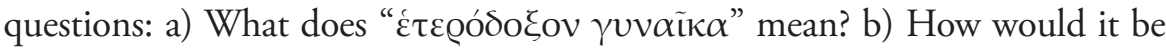
possible to have children from such a marriage if this marriage was forbidden by the Canonical Tradition of the Church, as we saw by the previous councils? c) What is the connection between baptism and marriage according to this canon? d) How can we understand the special condition for allowing such a marriage?

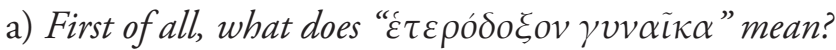

For both ancient and modern translators, it was difficult to render this phrase in their own language. For example, Dionysius Exiguus translated the phrase

61 Greek text from: Răzvan Perșa, Canoanele Bisericii Ortodoxe. Vol. 1: Canoanele Apostolice şi Canoanele Sinoadelor Ecumenice. Studiu introductiv, introduceri, note și traducere Răzvan Perşa, Bucharest, Basilica 2018, p. 224. English translation from: Norman P. Tanner, Decrees of the Ecumenical Councils: Nicaea I to Lateran V. Vol. 1, London, Sheed \& Ward 1990, p. 94. 62 E. Schwartz, Acta Conciliorum Oecumenicorum, II.1.3, Berlin, Walter de Gruyter, p. 95; idem, "Die Kanonessammlungen", p. 1-114; P. L'Huillier, "Origines et développement", p. 53-65; Aram Mardirossian, La collection canonique d'Antioche: droit et hérésie à travers le premier recueil de législation ecclésiastique (IVe siècle), Paris, ACHByz 2010, p. 42. 
with "sectae alterius uxorem". ${ }^{3}$ The same expression can be found in Hispana. In Prisca we find "alterius hereseos". ${ }^{64}$ The English translations render this phrase with: "a heretic woman", 65 "a heterodox woman", ${ }^{66}$ "a wife of heterodox views", ${ }^{67}$ "a wife that is of a different faith" ${ }^{68}$ Does the canon forbid marriage with any woman of different faith or just with heretic women? ${ }^{39}$ The word

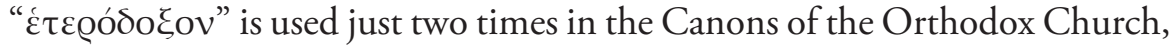
in Canon 14 of the Fourth Ecumenical Council, and in Canon 2 of the Council in Trullo, with reference to the interpolations found in the books of

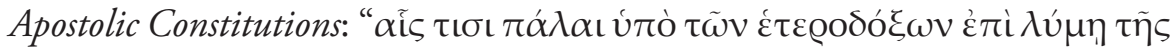

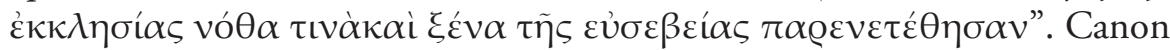
2 of the Council of Trullo considers these heterodox persons as heretics: "in no wise admitting the notions of heretical falsehood, nor inserting them in the genuine and perfect teaching of the Apostles". In the patristic literature

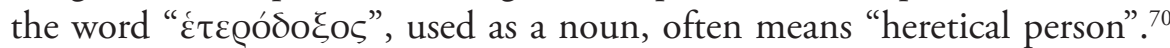

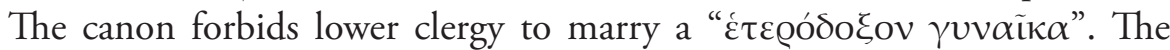

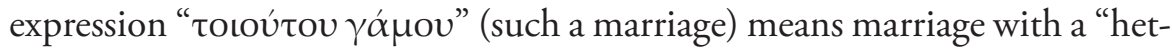
erodox wife or woman". The most important aspect that had to be solved was the relationship of Orthodox believers with heretics. According to the canon,

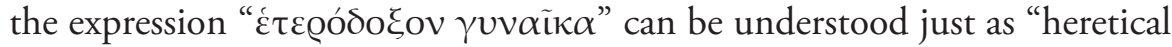
wife or woman" because the second part explicitly calls them heretics.

b) How would it be possible to have children from such a marriage if this marriage was forbidden by the Canonical Tradition of the Church, as we saw by the previous councils?

Canon 14 of the Fourth Ecumenical Council represents evidence of the fact that previous canons of the Local Councils were not applied with strictness

63 A. Strewe, Die Canonessammlung, p. 102.

64 P. L'Huillier, The church of the ancient councils, p. 315, n. 362.

65 Richard Price, The acts of the Council of Chalcedon. 3. Sessions XI-XVI, documents after the Council: appendices, glossary, bibliography, maps, indices, Liverpool, Liverpool University Press 2010, p. 99.

66 P. L'Huillier, The church of the ancient councils, p. 241.

67 N. P. Tanner, Decrees of the Ecumenical Councils, p. 94.

68 The Rudder, p. 259.

69 P. L'Huillier, The church of the ancient councils, p. 242-243. Unfortunately, the interpretation of P. L'Huillier does not analyse any detail of the canon, being just a simple overview regarding the issue of mixed marriages. There is no extensive interpretation of this canon in the study of L. J. Patsavos, "Mixed marriages", p. 244.

70 Geoffrey William Hugo Lampe, A patristic Greek Lexicon, Oxford, Clarendon Press 1995,

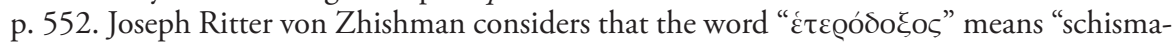
tic". Despite this, Zhishmann admits that the canon speaks further just about heretics and Canons 10 and 31 of the Council of Laodicea forbid marriages with heretics. Joseph Ritter von Zhishman, Das Eherecht der orientalischen Kirche, Wien, W. Braumüller 1864, p. 541. 
in the Church and members of the laity and lower clergy married "heterodox women". In his brief interpretation of Canon 14 of the Fourth Ecumenical Council, Peter L'Huillier affirms: "Canons 10 and 31 of Laodicea, appearing in the collection used by Fathers of Chalcedon, forbade all Christians from marrying heretics. Canon 14 of Chalcedon only urges the application of this norm to readers and chanters. No doubt, this ruling was poorly observed by many laymen. Since readers and chanters were at the limit between the clergy and the laity, they neglected it also". ${ }^{71}$ Those who contracted such a marriage must raise their children in the Orthodox Church: "if they have already had the children baptised by heretics". As we can see, the canon speaks about marriages with heretics and about the children that have been baptised by heretics, forbidding children of Orthodox believers to marry heretics, Jews or pagans. If we analyse the Byzantine state legislation from this period, we can see that marriage with Jews or pagans was not a real problem. ${ }^{72}$ Emperors Valentinian, Theodosius and Arcadius had already forbidden any marriage between Jews and Christians. The law given at Thessalonica April 30 (388) states that:

No Jew shall marry a Christian woman, nor a Christian man a Jewess. And if anyone does anything of the kind, the act shall be considered in the nature of adultery, and liberty of accusation is given to everyone. ${ }^{73}$

The real problem of the Council was the mixed marriages of minor clergy with heterodox persons and the relation between heretics and Orthodox.

c) What is the connection between baptism and mixed marriages according to this canon?

As in the canons of the Council of Laodicea, Canon 14 of the Fourth Ecumenical Council linked marriage with baptism, the heretic spouse has to promise that he will convert to Orthodoxy. Canon 14 of the Fourth Ecumenical Council states that "if they have already had the children baptised by heretics, they are to bring them into the communion of the catholic church". What does this mean? Do they have to be rebaptised, or can they be accepted by the Church as they are? The interpretation of Zonaras is very important for the meaning of this passage, by saying that:

This council forbade Orthodox clergymen to marry heterodox women, but to those who had already married and had children with them, it demands that all their children should be brought into the Catholic Church, even if they have already been baptized

\footnotetext{
P. L'Huillier, The church of the ancient councils, p. 243.

72 S. Troianos, "Die Mischehen ", p. 98.

73 Clyde Pharr et al., The Theodosian Code and Novels, and the Sirmondian Constitutions, Princeton, Princeton University Press 1952, p. 70.
} 
by heretics, because those who are brought may be Christianized, being either anointed with Holy Myrrh, if they were baptized by heretics whose baptism is reckoned to be acceptable to the Church; or be baptized again, if the baptism of the heretical ones that baptize them is rejected by the Church. And if the baptism has not yet been done, let them not be baptized by heretics, nor in the name of their children unite them with the heretics, neither with the Jews, nor with the pagans. 'Heretics' are said to be those that receive our Sacrament but that are mistaken in something, and are in disagreement with the Orthodox, 'Jews' are those who have killed Christ, and 'pagans' are those who are totally unbelievers and those who are worshiping idols. ${ }^{74}$

Theodor Balsamon divides heretics into two categories:

For you have seen that heretics are divided into two categories, into those that received our Mystery and the divine condescension, but who are mistaken in some things, and when they come to us, we anoint them only with myrrh, and into those that absolutely do not receive this, who are unfaithful, i.e., Jews and Greek, whom we also baptize. ${ }^{75}$

d) How can we understand the special condition for allowing such a marriage? The Byzantine Canonists believed that the heretic has to come to the Orthodox faith and then the marriage can be completed. Zonaras states that:

if the heretic or unbeliever promises to accept the Orthodox faith, then the agreement goes further, but the union is postponed until the promise of the one who has made it is fulfilled. And whoever violates these should be subjected to canonical punishment. ${ }^{76}$

The end of Balsamon's interpretation is very important for our topic.

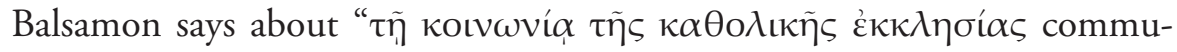
nion of the Catholic Church" that:

So by the word 'communion' both of them are indicated, so that they must be either anointed with Myrrh, or baptised. Read the

74 G. A. Rhalles, M. Potles (eds.), $\Sigma v ́ v \tau \alpha \gamma \mu \alpha \tau \tilde{\omega} v \theta \varepsilon i \omega \omega v$, p. 252. For English translation see: Patrick Viscuso, "Marriage between Orthodox and Non-Orthodox: A Canonical Study", in: Greek Orthodox Theological Review 40 (1-2/1995), p. 236. Despite the fact that Nikodemus the Hagiorite accepts the interpretation of Zonaras regarding the acceptance of the baptism of some heretics, he believed that: "though it would be more correct and safer for them to be baptized, seeing that the baptism of all heretics is in the nature of a pollution, and not a baptism; read also the interpretations of Ap. cc. XLVI, XLVII, and LXVIII". The Rudder (Pedalion) of the Metaphorical Ship, p. 259.

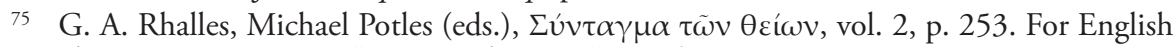
translation see: P. Viscuso, "Marriage between", p. 240.

${ }^{76}$ G. A. Rhalles, Michael Potles (eds.), $\Sigma u ́ v \tau \alpha \gamma \mu \alpha \tau \tilde{\omega} v \theta \varepsilon i ́ \omega v$, vol. 2, p. 252. For English translation see: P. Viscuso, "Marriage between", p. 236. 
Canon 7 of the Second Ecumencial Council, the $1^{\text {st }}$ chapter, title 4, book 28 of Basilicales and Canon 72 of the Council of Trullo, and notice that, probably on the basis of this canon, the member of the Church compels the Latins who want to take wives

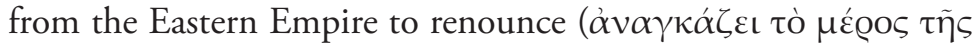

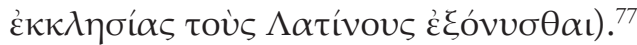

It is very important to state that Balsamon did not say in this commentary that the Latins have to be re-baptised, but that they have to renounce or to deny their different teachings upon oath $(\dot{\varepsilon} \xi$ óvvo $\theta \alpha \mathrm{l}) .{ }^{78}$ According to his statement, Latins were received into the Orthodox Church by a profession of faith. ${ }^{79}$

We can observe, as by the interpretation of the canons of the Council of Laodicea, that Byzantine Canonists understood this final part of the canon as requiring a postponement of the marriage and an immediate conversion of the heterodox spouse. As we saw in the text of Canon 31 of Laodicea, this canon does not say: "if that person converts to the Orthodox faith $\varepsilon i \mu$ iे

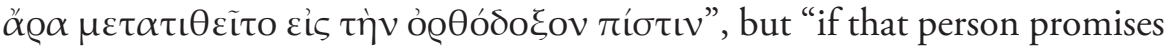

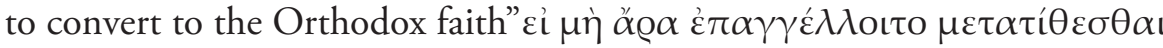

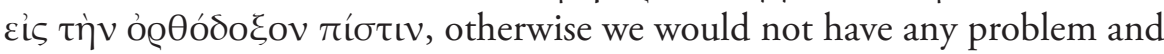
the canonical provision would be superfluous because this kind of marriage would be between two Orthodox believers and not between a heterodox person and an Orthodox believer. ${ }^{80}$ From this canon, as well as from Canon 31 of the Council of Laodicea, it can be asserted that the Church did not stipulate any immediate conversion of the non-Orthodox spouse and the marriage was not grounded on immediate baptism, but on the willingness of the heterodox person to promise and accept the Orthodox teachings. ${ }^{81}$

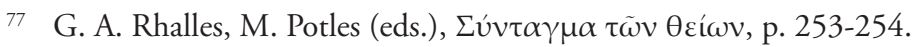

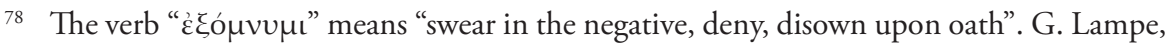
A Patristic Greek Lexicon, p. 499.

79 The fact that Latins should be received into the Orthodox Church just by profession of faith is shown by Balsamon in his sixteenth answer to Mark of Alexandria: "A member of the Latin race ought not to be sanctified through the divine and undefiled Mysteries, unless he first promises to refrain from Latin dogmas and customs, is instructed in the canons, and lives as an Orthodox". P. Viscuso, "Marriage between", p. 241.

80 S. Troianos, "Die Mischehen”, p. 95. A different opinion is shared by: Nicolae Dură, Teodosie Petrescu, "The Mixed Marriages According to the Orthodox Canonical Legislation", in: Ecumeny and Law 1 (2013), p. 120-121. The authors of the study affirm that: "However, the marriage of the Orthodox Christians with the heterodox has been permitted only then when the heterodox side was converting to "Orthodoxy» (Canon 31 of Laodicea; Canon 14 of the $4^{\text {th }}$ Ecumenical Synod), that is, the heterodox was becoming subject of the canon law of the Church by the Mystery of Baptism, thus also becoming worthy of receiving the other Mysteries of the Christian initiation, Chrismation, and Holy Communion."

81 P. D. Vlaicu, "Biserica Ortodoxă”, p. 175. 


\section{Intermarriage according to Canon 72 of the Council of Trullo}

The most important canon of the Canonical Tradition of the Orthodox Church regarding the issue of intermarriage or mixed marriage is Canon 72 of the Council of Trullo, considered normative for the Orthodox Church and accepted by the Western Church in its canonical legislation. ${ }^{82}$

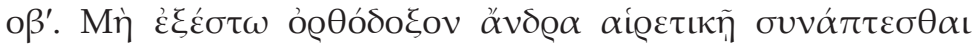

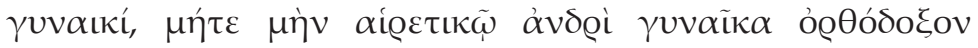

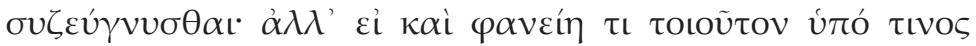

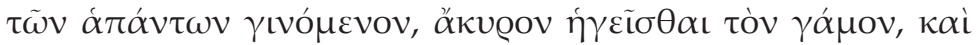

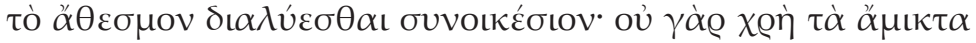

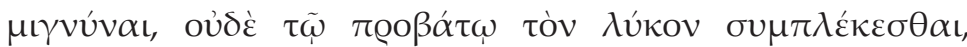

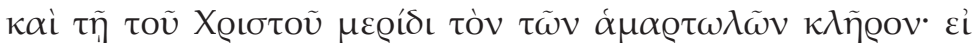
$\delta \dot{\varepsilon} \pi \alpha \varrho \alpha \beta \tilde{\eta} \tau \iota \varsigma \tau \dot{\alpha} \pi \alpha \varrho^{\prime} \dot{\eta} \mu \tilde{\omega} \nu$ ó

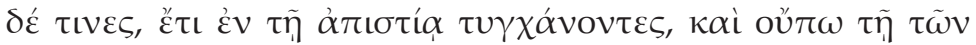

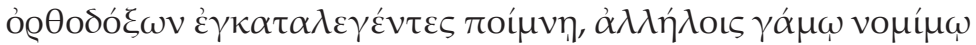

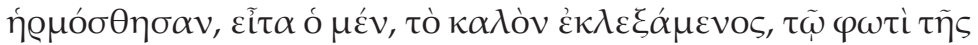

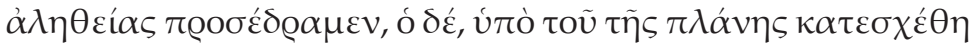

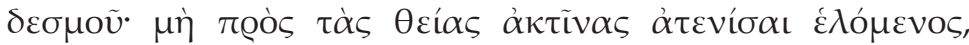

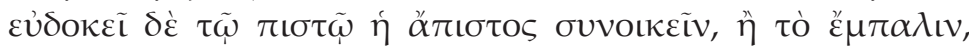

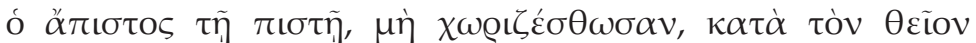

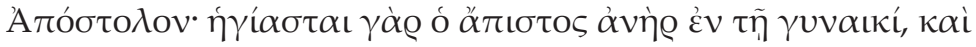

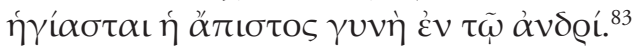

82 John P. Beal, "Canon 72 of The Council of Trullo in Catholic Jurisprudence: An Adventure in Ecumenism”, in: The Jurist: Studies in Church Law and Ministry 75 (1/2015), p. 35-57; William W. Bassett, "The Impediment", p. 383-415. For the reception of the Council of Trullo in the Western Church and Western Canon Law see: Frederick R. McManus, "The Council in Trullo: A Roman Catholic Perspective", in: The Greek Orthodox Theological Review 40 (1-2/1995), p. 79-96; Peter Landau, "Überlieferung und Bedeutung der Kanones des Trullanischen Konzils im westlichen kanonischen Recht", in: Georg Nedungatt, Michael Fetherstone (eds.), The Council in Trullo revisited, Kanonika 6, Roma, Pontifical Oriental Institute 1995, p. 215-216; H. Ohme, "The Causes of the Conflict", p. 17-43.

83 Greek text: R. Perșa, Canoanele Bisericii Ortodoxe, p. 315. English translation: "No Orthodox man shall be allowed to marry an heretical woman, nor any Orthodox woman an heretical man; and if such a thing is found to have been done, the marriage is to be considered invalid and the unlawful cohabitation to be dissolved. For one must not mix things which are pure, nor join a wolf to a sheep and the portion of Christ to the lot of sinners. If anyone transgresses against our decree, he shall be excommunicated. But in the case of those joined in lawful marriage whilst still unbelievers, not yet admitted to the fold of the Orthodox, should one of them thereafter choose the good and come to the light of truth, whereas the other be detained by the bonds of error and choose not to gaze upon the divine splendour, if the unbelieving woman is content to cohabit with the believing man, or again, the unbelieving man with the believing woman, they should not be separated, in accordance with the divine Apostle: 'For the unbelieving husband is made holy through his wife, and the unbelieving wife is made holy through her husband"'. For the English translation of the can- 
Before analysing the text and context of the canon, it is very important to emphasise the fact that Canon 72 of the Council of Trullo is a text of great interest in the current canonical Orthodox and Catholic debate, and we can identify two main issues regarding its validity and application, and its content. Regarding the validity and application of Canon 72 of Trullo some scholars consider this text as abrogated or fallen into desuetude, ${ }^{84}$ but others believe that it is still valid and normative for the Orthodox Church and expresses the strictness of the Canonical Tradition ${ }^{85}$. Those who affirm the current validity of Canon 72 of Trullo emphasise the fact that this canon does not just forbid marriages with heretics, but it considers them to be void and declares their dissolution as obligatory.

Regarding the content of the canon, it is important to determine: a) if the canon refers to heretics and schismatics as well? b) What do "žkvoov

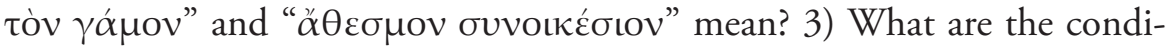
tions for allowing such a marriage?

a) Does the canon refer to heretics and schismatics as well? Canon 72 of the Council of Trullo speaks about heretic woman and her-

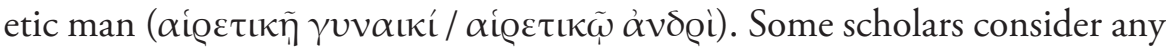
distinction between heretics and schismatics as inappropriate, the canon being applied to all persons of a different faith. ${ }^{86}$ The concept of heresy can

ons of Trullo I will use the edition of: G. Nedungatt, M. Fetherstone, The Council in Trullo, p. 153-154. For other English translations of these canons see: The Rudder, p. 283-413; H. R. Percival, "The Seven Ecumenical Councils", p. 359-365. For the French translation, see: P. P. Joannou, Discipline générale antique, p. 101-241; and the latest translation of Archim. G. D. Papathomas, Le Corpus Canonum, p. 851-969.

84 For the validity of the canon in current Canon Law debate see: J. P. Beal, "Canon 72", p. 35-57.

85 N. Milaș, Canoanele Bisericii Ortodoxe, p. 450: "Aceasta este în sensul strict doctrina canonică a Bisericii ortodoxe în chestiunea prezentă, și după cum doctrina aceasta a fost în vigoare în cursul tuturor veacurilor în Biserica ortodoxă , astfel trebue să rămână în vigoarei astăzi și totdeauna." "This is the strict canonical doctrine of the Orthodox Church in the present matter, and as this doctrine has been in force throughout the ages in the Orthodox Church, it must remain in force today and forever."). For the same opinion see: C. G. Pitsakis, "Les mariages mixtes", p. 107.

86 N. Milas, Canoanele Bisericii Ortodoxe, p. 450; H. Ohme, Concilium Quinisextum: Das Konzil Quinisextum, Fontes Christiani 82, Turnhout, Brepols 2006, p. 76-77; L. J. Patsavos, "Mixed marriages", p. 245. The most prominent voice is that of Nikodemus the Hagiorite. St. Nicodemus the Hagiorite accepts the necessity of rebaptism of heretics and schismatics that can be found in the canon of St. Cyprian of Carthage and applies it to the realities of his century. However, a thorough analysis of the concept of "heretic" and "schismatic" in the work of St. Cyprian shows that in the theology of the Carthaginian bishop the two terms are often interchangeable, the difference between "heresy" and "schism" being a subsequent theological development, as it can be seen in the first canon of St. Basil the Great or in the work of Sf. Augustine. Geoffrey D. Dunn, "Heresy and Schism in Cyprian of Carthage", in: Journal of 
be developed, as for the previous canons, in accordance with the baptismal theology of the Council of Trullo, Canon 95 being the most important one. ${ }^{87}$ The Council of Trullo considered all teachings of different religious

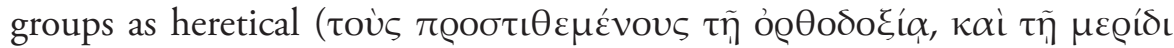

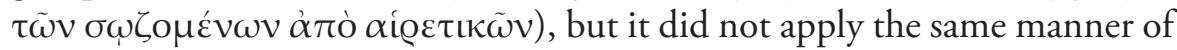
reception of these heretics into the Orthodox Church, as we have seen in the Canons of the Council of Laodicea and in the interpretations of Canon 14 of the Fourth Ecumenical Council. A certain distinction between them is made by the Council. Canon 95 of the Council of Trullo uses the word "heresy" for all these groups: those who are received by Chrismation are forced to anathematize the heresy ( $\left.\dot{\alpha} v \alpha \theta \varepsilon \mu \alpha \tau i \zeta \zeta o v \tau \alpha \varsigma \pi \tilde{\alpha} \sigma \alpha v \alpha i{ }^{\prime} \rho \varepsilon \sigma \iota v\right)$. Those that have to

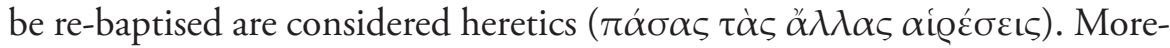
over, even those who are only received by a confession of faith come to the

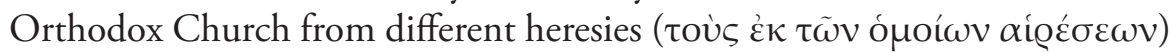

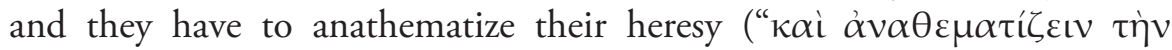

Theological Studies 55 (2004), p. 551-574; Maureen Tilley, "When Schism Becomes Heresy in Late Antiquity: Developing Doctrinal Deviance in the Wounded Body of Christ", in: Journal of Early Christian Studies 15 (2007), p. 1-27; Rowan Williams, "Defining Heresy", in: Allen Kreider (ed.), The Origins of Christendom in the West, Edinburgh, T\&T Clark 2001, p. 313336; Gerald Bonner, "Dic Christi Veritas Ubi Nunc Habitas: Ideas of Schism and Heresy in the Post-Nicene Age”, in: William E. Klingshirn, Mark Vessey (eds.), The Limits of Ancient Christianity: Essays on Late Antique Thought and Culture in Honor of R. A. Markus, Ann Arbor, University of Michigan Press 1999, p. 63-79. For the canonical vision regarding the reception of converts to Orthodoxy in the theology of St. Nicodemus the Hagiorite see: John H. Erickson, "On the Cusp of Modernity: The Canonical Hermeneutic of St. Nikodemos the Hagiorite (1748-1809)", in: St. Vladimir's Theological Quarterly 42 (1998), p. 45-66; Heith-Stade David, The Rudder of the Church. A Study of the Theory of Canon Low in the Pedalion, Lund, Lund University 2014; J.H. Erickson, "The Problem of Sacramental Economy", in: idem, The Challenge of Our Past, Crestwood, St. Vladimir's Seminary Press 1991, p. 115-132. The interpretation of Nikodemus the Hagiorite for this canon is categorical: "Let those prelates fear the penance of the present Council who are in the island provinces and all those regions where there are Latins; and by no means and on no account whatsoever let them allow a Latin man to marry an Orthodox woman, or a Latin woman to take an Orthodox man to husband. For what communion can there be of the Orthodox party with the heretic? But if it should so happen in any way that without their recognizance such lawful marriages are actually contracted, let them at once proceed to separate them, in accordance with this Canon, unless the Latin-minded person be baptized in a strictly Orthodox manner." The Rudder, p. 376-377.

87 For its interpretation see: Kallistos Ware, "The Rebaptism of Heretics in the Orthodox Canonical Tradition”, in: Andrew P. Roach, James R. Simpson (eds.), Heresy and the Making of European Culture: Medieval and Modern Perspectives, Abingdon-on-Thames, Routledge 2016, p. 31-50; George D. Dragas, "The manner of reception of Roman Catholic converts into the Orthodox Church with special reference to the decisions of the Synods of 1484 (Constantinople), 1755 (Constantinople) and 1667 (Moscow)”, in: Greek Orthodox Theological Review 44 (1999), p. 235-271; J. H. Erickson, "The Reception of Non-Orthodox into the Orthodox Church: Contemporary Practice", in: Saint Vladimir's Theological

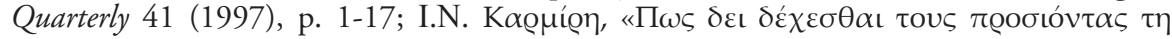

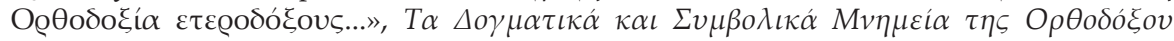

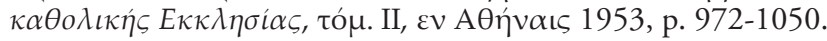




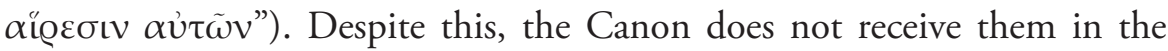
same manner. According to this, the Council of Trullo makes a distinction between the dogmatic meaning of heresy and canonical meaning, all the other religious groups come from different heretical teachings and profess heresies, but not all of them are received in the same manner into the Orthodox Church, because the baptism of some groups is recognised by the Church. Taking into consideration the fact that Canon 95 of the Council of Trullo is based on Canon 7 of the Second Ecumenical Council, Canon 19 of the First Ecumenical Council, Canon 1 of St. Basil the Great, Canons 7 and 8 of the Council of Laodicea, it is certain that the distinction between heretics, schismatics, and illicit assemblies is made by the Council of Trullo. ${ }^{88}$

If we consider the second part of Canon 72 of Trullo an explanation for the first part, then we can conclude that the "heretics" are the same as un-

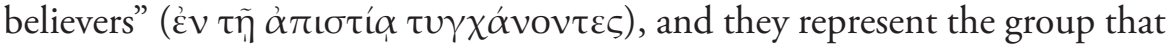
must be re-baptised when they are received into the Orthodox Church. ${ }^{89}$ The Fathers of the Church considered this kind of heretic as pagans, nonbaptised, whose baptism was invalid for the Orthodox Church. ${ }^{90}$ This can be the reason why the Fathers of the Council were so harsh in addressing this group: "one must not mix things which are pure, nor join a wolf to a sheep and the portion of Christ to the lot of sinners".

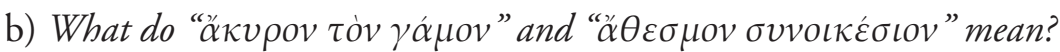
If the other canons of the Orthodox Church did not impose any canonical punishment for contracting such marriages, the canon of Trullo would prescribe three drastic punishments: invalidity of the marriage (äkv@ov

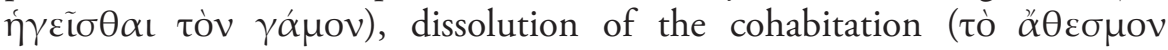

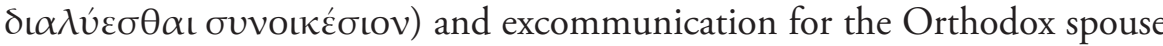
$\left(\dot{\alpha} \varphi \operatorname{co\iota }_{\zeta} \dot{\varepsilon} \sigma \theta \omega\right)$. The problem of mixed marriage in this period cannot be seen as a doctrinal problem, because the sacramental Theology of Marriage was not yet developed. ${ }^{91}$ It is anachronistic to affirm that the service of marriage was taken out of the Liturgy because of mixed marriages, as some Orthodox theologians try to argue. ${ }^{92}$ They think that the service of marriage

${ }_{88}$ For the interpretation of the first canon of Sf. Basil the Great see André de Halleux, "«Oikonomia» in the first canon of Saint Basil", in: The Patristic and Byzantine Review (6/1987), p. 53-64. (This article is an English translation of: André de Halleux, "L'économie dans le premier canon de Basile", in: Ephemerides Theologicae Lovanienses 62 (4/1986), p. 381-392). For a different opinion, see: Mario Girardi, "Nozione di eresia, scisma e parasinagoga in Basilio di Cesarea”, in: Vetera Christianorum 17 (1980), p. $49-77$.

89 For a similar opinion see: S. Troianos, "Die Mischehen”, p. 98.

90 W. W. Bassett, “The Impediment”, p. 399.

91 C. G. Pitsakis, “Les mariages mixtes”, 107-120.

92 L. J. Patsavos, "Mixed marriages", p. 243-256. John Meyendorff, Marriage: An Orthodox Perspective, $4^{\text {th }}$ edition, Crestwood, St. Vladimir's Seminary Press 2000, p. 37: "The only compromise which the Church could not accept, however, was to mitigate the holiness of the Eu- 
was removed from the Liturgy because the Church allowed mixed marriages and by this, a rupture between Eucharist and Liturgy as well between sacramental theology of marriage and Eucharist occurred, and those kinds of marriages did not have a full sacramental value. ${ }^{93}$ The liturgical Tradition of the Orthodox Church contains several short prayers for the marriage that were performed during the Liturgy, ${ }^{94}$ but there was no extensive ceremony or any solemnization of the marriage before the ninth century. We can ask ourselves: can the union of heretics and Orthodox be seen as illegal according to Roman Byzantine Law, or just by the Church Canon Law? As we can see from different legal texts, the Roman Byzantine legislation did not forbid marriages between Orthodox and heretics before the Council of Trullo, but it tried to discourage them. ${ }^{95}$ It is obvious from these legal texts that the Council of

charist: it could not, for example, give communion to a non-Orthodox, or to a couple entering a second marriage. Thus, it had to develop a rite of marriage separate from the Eucharist. The change was made more acceptable by the fact that the obvious connection between Church marriage and Eucharist was lost anyway as soon as Church marriage became a legal requirement.". For a similar opinion see: G. D. Papathomas, "Un Communautarisme ecclésial ouvert: mariages disparsmixtes et conversions d'adultes", in: Synaxie 96 (10-12/2005), p. 36-47.

93 John Meyendorff says that: "Baptism, in the Early Church, was celebrated during the Liturgy, and so are, even today, the services of ordination to the diaconate, the priesthood, and the episcopate. This was originally the case with marriage. Only this understanding of Christian marriage as an integral part of the Mystery, of which the Eucharist is the 'completion,' can explain the canonical regulations against 'mixed marriages,' against 'second marriages,' etc., as we shall see below. These marriages could not be fully sacramental. Perfectly 'legitimate' in terms of civil law, they could not be integrated into the Eucharist". J. Meyendorff, Marriage: An Orthodox Perspective, p. 22.

94 Ibidem, p. 24-25.

95 Codex 1.5.18.8: "If a heretic husband cohabits with an Orthodox wife, or, on the contrary, a heretic wife has an Orthodox husband, their children shall be brought up in the Orthodox faith, and if it happens that some of those children become Orthodox while others, for any reason remain adherents of the same or some other heresy, then only the Orthodox children shall be heirs of the father and mother, and so that the others shall have no claim on the maternal or paternal inheritance". The same thing can be found in the Novel 115.3. 14-15. Codex. 1.4.16: "The same Emperors to Erythrius, Praetorian Prefect. If a hoped-for marriage is not forbidden by the laws, and the woman refuses to marry the man after the betrothal-money is given, on account of diversity of religion, and it is proven that the woman or her parents knew about this before the betrothal-money was given, they have no one but themselves to blame. But if the received the betrothal money without knowledge of the fact, or such cause for repentance arises thereafter, they need to return only what they received and are released from paying twice the amount. This, in like manner, shall apply to the betrothed man, as to receiving back the betrothal- money furnished. Given at Constantinople, July 1 (472)." Codex 5.1.5.3. "We add also that if the hoped-for nuptials were not forbidden by the laws and the woman refuses to marry the man after betrothal-money is given on account of his unseemly or immoral conduct or on account of diversity of religious belief, or because the man is incapable of cohabitation from which the hope of offspring arises, or because of other just excuses, but it is proven that the women or her parents knew this before betrothal-money was given, they have no one but themselves to blame." 
Trullo was imposing a stricter canonical rule on marriages with heretics that influenced as well the development of legal texts in the $8^{\text {th }}$ and $9^{\text {th }}$ centuries. ${ }^{96}$

c) What are the conditions for allowing such a marriage?

The final part of Canon 72 of the Council of Trullo is very important for our topic. As the Orthodox bishop and canonist Nicodim Milasch says: "by admitting this, the canon allows the possibility of the so-called mixed mar-

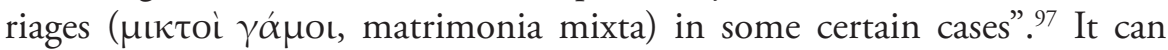
be seen that the Fathers of the Council are allowing such marriages if both spouses were legally married and one of them became Orthodox according to the teaching of Apostle Paul (1 Corinthians 7, 12-14)..$^{98}$ In this case, if the non-Orthodox spouse agrees, the marriage is recognised by the Church and the Orthodox spouse is received into the communion of the Orthodox Church. Before analysing the pastoral and canonical meaning of this last part of the canon, it is very important to see the meaning of the phrase "

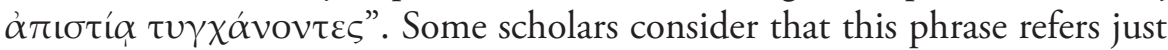
to pagans, showing that paganism was still alive at the end of the seventh century. ${ }^{99}$ Some other scholars consider, that there is no difference, as we showed above, between this kind of heretic and pagans. ${ }^{100}$ This is the reason why the Fathers of the Council of Trullo give this canonical disposition for both heretics and pagans. From a historical point of view, the distinction between "matrimonia mixta" and "mixta religio" cannot be endorsed for this period. Saint Nikodemus the Hagiorite considers that this last part of the canon applies to heretics as well. ${ }^{101}$

If we compare the two parts of the canon, at first sight, an evident contradiction between them can be spotted. According to its first part, the canon rejects any cohabitation between an Orthodox and a non-Orthodox, imposing three punishments: invalidity of the marriage, dissolution of the cohabitation and excommunication for the Orthodox spouse. Despite this, the second part of the canon allows such a marriage if it was contracted before one of the spouses converted to Orthodoxy. In this case, the marriage

96 For these texts see: S. Troianos, “Die Mischehen”, p. 99-100.

97 N. Milaș, Canoanele Bisericii Ortodoxe, vol. I.2, p. 447.

98 For a recent interpretation of this passage see: Stephen C. Barton, "Sanctification and Oneness in 1 Corinthians with Implications for the Case of 'Mixed Marriages' (1 Corinthians 7.12-16)", in: New Testament Studies 63 (1/2017), p. 38-55.

99 Demetrios J. Constantelos, “Mixed Marriage in Historical Perspective”, in: Greek Orthodox Theological Review 40 (3-4/1995), p. 282.

100 W. W. Bassett, "The Impediment”, p. 399.

101 "But if both parties were in the heresy of the Latins to begin with and one party afterwards takes to Orthodox, their children must all be brought up as Orthodox Christians in accordance with the civil laws". The Rudder, p. 377. 


\section{Răzvan Perșa}

is considered accepted by the Fathers, and the Orthodox spouse is received into the communion of the Church, despite the fact that the other spouse is "detained by the bonds of error and chose not to gaze upon the divine splendour". The second part of the canon shows that the canonical prohibition of mixed marriages is not a doctrinal one, otherwise the canon would reject any cohabitation between Orthodox and non-Orthodox, but rather it is a pastoral, canonical and disciplinary measure in order to suppress the spread of heretical doctrines and teachings.

\section{Conclusions}

The canons of the Church express both the canonical akribeia of the Church, according to which mixed marriages are totally prohibited, as well the oikonomia, allowing in special conditions Orthodox believers to live in a lawful marriage with non-Orthodox spouses. In the same canons (Canon 31 of Laodicea, Canon 14 of Fourth Ecumenical Council, Canon 72 of Trullo) we can find the expression of akribeia and oikonomia, without having a socalled legal contradiction, which is possible only if we consider the canons of the Church as a positivistic legal system of Law.

The definition of "heresy" and "heretics" must be seen according to the baptismal theology of the Councils and the reception of non-Orthodox into the Orthodox Church.

The Councils that we have analysed considered all teachings of different religious groups as heretical, but they did not apply the same manner of reception of these heretics into the Orthodox Church. A certain distinction between them is made by the Council because of this manner of reception. This proves to us that, despite the lack of a terminological distinction between different heretical groups, the Church and the Fathers of the Councils did not consider them as totally separate from the Church, and that the doctrinal and canonical definition of heresy and heretics is different.

The canonical prohibition of mixed marriages, according to canonical akribeia, does not exclude the possibility of Church oikonomia, and is not a doctrinal expression of the faith, otherwise the canons would reject any cohabitation between Orthodox and non-Orthodox, even if one spouse converts to Orthodoxy, but rather it is a pastoral, canonical and disciplinary measure in order to suppress the spread of heretical doctrines and teachings. 